\title{
MiNIREVIEW
}

\section{Autoimmune Melanocyte Destruction in Vitiligo}

\author{
René van den Wijngaard, Anna Wankowicz-Kalinska, Steven Pals, Jan Weening, \\ and Pranab Das
}

Department of Pathology, Academic Medical Center, Amsterdam University, Amsterdam, The Netherlands

V

itiligo is a disorder of pigmentation characterized

by the presence of milk-white skin macules. The term vitiligo may have evolved from either the Latin word vitium, meaning fault, or vitelius meaning spotted calf (Kovacs, 1998). Pigment-producing cells (melanocytes) are absent from vitiligo lesions (Le Poole et al, 1993b); their loss represents a key event in the pathogenesis of the disease. Vitiligo lesions can change in size and shape over time and can develop at any age, but in approximately half of all cases the disease onset is before the age of twenty (Lerner, 1959). Clinical presentations include (a) segmental vitiligo, characterized by lesions that occur in a dermatomal, asymmetric distribution (of limited clinical significance); (b) focal vitiligo, characterized by a limited number of small lesions; (c) generalized vitiligo, the most common type of vitiligo, where lesions occur with bilateral, symmetrical distribution; and (d) universal vitiligo, indicating complete or almost complete depigmentation (Mosher et al, 1993). The incidence of this disease varies greatly between populations (from $0.14 \%$ to $8.8 \%$ ), but the worldwide incidence is considered to be between 1\% and 2\% (Mosher et al, 1993). As well as the enhanced ultraviolet (UV) sensitivity of depigmented spots, vitiligo also is a cosmetically disabling disorder that often leads to psychologic stress (Porter et al, 1979). In addition, due to the occurrence of similar hypopigmented skin lesions in the early phase of leprosy, vitiligo is a true social stigma in countries in which leprosy is endemic. This problem is probably best emphasized by the terminology used in southern India, where vitiligo is known as ven kushtam, meaning "white leprosy" (Mosher et al, 1993).

There are three main hypotheses for the pathogenesis of vitiligo: self destruction, neural, and autoimmune (Kovacs, 1998). In a number of recent studies,

Received January 31, 2001.

This research was carried out under project GNK/PA/ODP1O and GNKI DE/ODP9 of the van Loghem Immunology Institute, Academic Medical Center, University of Amsterdam, The Netherlands.

Address reprint requests to: Dr. P. K. Das, Department of Pathology (Room L-2-258), Meibergdreef 9, 1105 AZ Amsterdam, The Netherlands. E-mail:p.k.das@amc.uva.nl strong evidence in favor of the autoimmune hypothesis has been obtained. This review will discuss the relevant new evidence for autoimmune melanocyte destruction in vitiligo.

\section{Ontogeny and Function of Normal Human Melanocytes}

Absorption of photons by cellular DNA may cause DNA damage (McGregor, 1999). Therefore, exposure to UV light is a major risk factor for the development of skin cancer (Lim and Cooper, 1999). In addition, oxygen radicals that are generated by UV irradiation (Danno et al, 1984) may significantly alter the properties of proteins, thus impairing their function in the control of cell growth and survival (Riley, 1994). Protection from these harmful effects of UV light is mediated by melanin, which is capable of directly absorbing UV light (Hearing, 1999) and functions as a scavenger of free oxygen radicals (Bustamante et al, 1993). In normal healthy skin, melanin is synthesized by melanocytes that are located in the basal layer of the epidermis. Melanin synthesis, a multistep process involving tyrosinase as a key enzyme (Sanchez-Ferrer et al, 1995), takes place in specialized organelles called melanosomes (Hearing, 1999). Through dendrite-like processes, melanin is transferred to the keratinocytes (Yamamoto and Bhawan, 1994) in which it forms supranuclear caps that reduce UV transmission to the nuclear content (Kobayashi et al, 1998).

Melanocytes are not found exclusively in the epidermal basal layer and hair roots, but also in the uvea and retinal pigment epithelium of the eye, and in the stria vascularis of the inner ear (Jimbow et al, 1993). This may explain why vitiligo is associated with ophthalmological and auditory defects (Ardic et al, 1998). Melanocytes originate from the neural crest (Jimbow et al, 1993); during ontogenesis they migrate from the neural tube toward the epidermal basal layer (WehrleHaller and Weston, 1995). This migration involves stem cell factor (SCF) and the SCF-receptor encoded by the c-Kit proto-oncogene (Kunisada et al, 1998; Wehrle-Haller and Weston, 1995). The final entry of melanocyte progenitors from dermis into the epidermis presumably is facilitated by high E-cadherin ex- 
pression levels on the melanoblasts (Nishimura et al, 1999). In the adult human skin, melanocytes constitute about $3 \%$ to $5 \%$ of the total epidermal cell population. Racial differences in pigmentation intensity are not due to variations in melanocyte density but rather to differences in the number of melanosomes per cell and the melanin content per melanosome (Jimbow et al, 1993).

Although protection from UV irradiation is the primary function of melanocytes, a newly recognized role is their participation in the immune system. Melanocytes can express major histocompatibility complex (MHC)-class I and II molecules and adhesion molecules, such as intercellular adhesion molecule (ICAM)-1 and vascular cell adhesion molecule (VCAM)-1 (al Badri et al, 1993; Le Poole et al, 1993a; Smit et al, 1993). In addition, they can produce several cytokines, such as interleukin (IL)-1, IL-6 (Smit et al, 1993), IL-8 (Zachariae et al, 1991), and transforming growth factor- $\beta 1$ (TGF- $\beta 1$ ) (Le Poole and Boyce, 1999). Furthermore, melanocytes are not only capable of phagocytosis (Le Poole et al, 1993c), but can also process antigen and present antigenic peptides to $T$ cells (Le Poole et al, 1993a). Melanocytes that present peptides from the 65-kd heat shock protein (HSP) of Mycobacterium leprae not only induce T cell proliferation, but also become the target of these cytotoxic $T$ cell clones. These studies indicate that melanocytes are nonprofessional antigen-presenting cells (APC), which leads to a new hypothesis on the destruction of melanocytes in vitiligo.

\section{Immune Mechanisms in the Pathogenesis of Vitiligo}

\section{Genetic Factors}

The extent of familial aggregation of vitiligo is statistically significant. The pattern of relationship between relative risk and degree of kinship indicates that the disease is associated with genetic loci on different chromosomes, which points to a polygenic nature of the disease (Das et al, 1985; Majumder et al, 1993). In relation to this, it is known that vitiligo is frequently associated with several other autoimmune diseases including uveitis (Park et al, 1992), diabetes mellitus (Gould et al, 1985), autoimmune thyroid disease (Hegedus et al, 1994), and atrophic gastritis (Zauli et al, 1986). Further, several positive human leukocyte antigen (HLA)-associations for vitiligo have been reported: HLA-A2, HLA-Dw7 (Buc et al, 1996), HLA-DR4 (Dunston and Halder, 1990; Foley et al, 1983), B13, Bw35 (Metzker et al, 1980), Cw7, and DR6 (Venneker et al, 1993).

The initiation of antigen-specific T-cell-dependent immune responses generally requires costimulation through CD28/B7(CD80 or CD86) ligation (McCoy and Le Gros, 1999). In addition, it was shown that interaction of APC expressed B7 with T-cell-expressed cytotoxic T-lymphocyte-associated molecule-4 (CTLA-4) delivers a negative signal for $\mathrm{T}$ cell response (McCoy and Le Gros, 1999). CTLA-4 gene polymorphisms were de- scribed in autoimmune diseases like Graves disease (Kotsa et al, 1997), autoimmune hypothyroidism (Kotsa et al, 1997), and Addison's disease (Kemp et al, 1998a). Therefore, it was suggested that aberrant CTLA-4 expression or function, based on such polymorphisms, may be related to the occurrence of these diseases. Recently, CTLA-4 gene polymorphism has been described in a group of vitiligo patients who also presented with other autoimmune diseases (Kemp et al, 1999). It was suggested that this polymorphism may confer susceptibility to autoimmune-mediated mechanisms of melanocyte destruction in vitiligo through inadequate self tolerance.

\section{Humoral Immune Response}

Antibodies reactive against melanocyte-derived antigens have been demonstrated in the serum of vitiligo patients. Several authors reported that the principle antigen recognized by these autoantibodies is tyrosinase (Fishman et al, 1997; Kemp et al, 1997; Song et al, 1994). Other melanocyte differentiation antigens that are recognized are gp100/Pmel17, and tyrosinase-related proteins (TRP)- 1 and TRP-2 (Kemp et al, 1998b, 1998c). These differentiation antigens all localize primarily to the melanosomes (Hearing, 1999), whereas it has been well established that antibodymediated killing requires membrane expression of the target antigens. Surprisingly, however, it was observed that patients' sera can induce in vitro damage to melanocytes via the classical pathway of complement activation and by antibody-dependent cellular cytotoxicity (Norris et al, 1988), and that at least some of the antibodies recognize membrane-expressed melanocyte antigens (Naughton et al, 1983a, 1983b; Yu et al, 1993). Further, it was shown that TRP-1 can be expressed on the cell surface of human and mouse melanoma cells (Takechi et al, 1996), suggesting that this differentiation antigen may represent a target for melanocyte destruction in vivo. Passive transfer of a monoclonal antibody against TRP-1 was found to induce melanoma regression as well as a patchy vitiligo-like depigmentation in mice (Hara et al, 1995; Takechi et al, 1996). Furthermore, it was shown that immunologic tolerance for TRP-1 in mice can be broken by active immunization with syngeneic TRP-1, when expressed in allogeneic cells or recombinant vaccinia virus (Naftzger et al, 1996; Overwijk et al, 1999), and also with "naked" plasmid DNA-encoding xenogeneic TRP-1 (Weber et al, 1998). In these melanoma models, vaccination-induced coat depigmentation was mediated by IgG class of anti-TRP-1 antibodies and occurred in the absence of detectable CTL responses.

The strongest evidence of a role for autoantibodies in melanocyte destruction in vitiligo was obtained in an in vivo model using nude mice grafted with normal human skin. When these mice were injected with purified IgG of vitiligo patients, it was observed that epidermal immunoglobulin deposits coincided with melanocyte destruction (Gilhar et al, 1995). However, reports on in situ immunoglobulin and complement 
deposits in human vitiligo are limited and contradictory (Abdel-Naser et al, 1994; Uda et al, 1984; Yu et al, 1993). Furthermore, these deposits were observed on keratinocytes and not melanocytes. Therefore, it is possible that these autoreactive antibodies are secondary to melanocyte destruction. Nevertheless, although they may not be of prime importance for the autoimmune reaction, autoantibodies may serve as a good prognostic marker for disease activity. Indeed, a correlation was shown between the presence and titer of antipigment cell antibodies and disease activity (Harning et al, 1991).

\section{Cellular Immune Response}

The first indications for a possible role for $T$ cells in the pathogenesis of vitiligo came from case reports on inflammatory vitiligo (Buckley, 1953; Garb and Wise, 1948; Michaelsson, 1968). In this rare disorder the depigmented lesion is surrounded by a raised red rim. Histopathologic investigations of the perilesional skin suggested the involvement of lymphocytes in the depigmentation process. Immunohistochemical studies have now confirmed the presence of infiltrating $T$ cells and their frequent apposition to perilesional melanocytes in this type of vitiligo (Le Poole et al, 1996; Yagi et al, 1997). Importantly, similar in situ T cell infiltrates with a predominant presence of $\mathrm{CD}^{+} \mathrm{T}$ cells have also been detected in common generalized vitiligo (Abdel-Naser et al, 1994; Badri et al, 1993; Gross et al, 1987; van den Wijngaard et al, 2000).

Recently, Melan-A-specific CD8 ${ }^{+} \mathrm{T}$ cells were identified in the peripheral blood of vitiligo patients by the tetramer technique (Ogg et al, 1998). Melan-A/ MART-1 is one of the melanocyte-specific differentiation antigens that is recognized by CTL in melanoma (Coulie et al, 1994). High numbers of Melan-A-specific $\mathrm{CD}^{+} \mathrm{T}$ cells were observed in 7 of 9 patients with HLA-A*0201-positive vitiligo (Ogg et al, 1998). The frequency of these cells among the total $T$ cell pool correlated with disease activity, and isolated Melan-A tetramer-positive $T$ cells were able to lyse HLAmatched melanoma cells in vitro. Moreover, the blood-derived Melan-A-recognizing cells expressed the skin-homing receptor cutaneous lymphocyte-associated antigen (CLA) (Picker et al, 1990). The importance of skin-homing $\mathrm{CD}^{+}{ }^{+} \mathrm{T}$ cells was confirmed in an in situ immunohistochemical investigation of perilesional skin samples (van den Wijngaard et al, 2000). Most of the melanocyte-apposing T cells were $\mathrm{CD}^{+}$/ $\mathrm{CLA}^{+}$, and the majority of these T cells also expressed the cytotoxic effector molecules perforin and granzyme. The latter finding is of particular importance because in vitro experiments have indicated that melanocytes are sensitive to the granule exocytosis pathway of apoptosis induction (perforin/granzyme), but resistant to the Fas-ligand-mediated pathway (Rivoltini et al, 1998; R. M. van den Wijngaard, A. Wankowicz-Kalinska, J. Aten, M. van den BerghWeerman, E. de Vries, K. Dingemans, J. Borst, P. K. Das, unpublished observation). Similarly, in a mouse melanoma regression model, autoimmune destruction of melanocytes could only proceed in the presence of perforin (Bowne et al, 1999).

Additional evidence for the importance of cellmediated immunity in the pathogenesis of vitiligo has come from the field of melanoma research. Early clinical observations indicated that the presence of vitiligo has a favorable influence on the average fiveyear survival rate of patients with malignant melanoma (Bystryn et al, 1987; Nordlund et al, 1983). Furthermore, II-2 based immunotherapy studies in melanoma patients suggested a role for autoreactive CTL in vitiligo (Rosenberg, 1997). In these studies, $26 \%$ of responding patients developed vitiligo in conjunction with melanoma regression, whereas no depigmentation was observed in nonresponding patients and in patients with unrelated malignancy. It should be emphasized that in vitro experiments demonstrated that CTL generated from melanoma tissue also recognize differentiation antigens expressed by normal human melanocytes (Anichini et al, 1993). Moreover, clonallyexpanded $T$ cells with identical $T$ cell receptor $V \beta$ regions were simultaneously demonstrated in the vitiligo-like halo around a regressing melanoma and within the melanoma (Becker et al, 1999). High numbers of Melan-A-specific CTL have been observed in the peripheral blood of vitiligo patients (Ogg et al, 1998) and in melanoma patients with concurrent vitiligo, but not in melanoma patients without vitiligo (Pittet et al, 1999). Moreover, regression of metastatic melanoma and the occurrence of vitiliginous skin lesions in response to immunization with Melan- $A$ peptide were both associated with oligoclonal expansion of Melan-A-reactive CTL (Jager et al, 2000). Also, when a patient with metastatic melanoma was infused with Melan-A-specific $\mathrm{CD}^{+} \mathrm{T}$ cells, this patient developed inflammatory skin lesions and depigmented spots that were associated with the local presence of these $\mathrm{T}$ cell clones (Yee et al, 2000).

Taken together, the accumulated data indicate that $\mathrm{CD}^{+} \mathrm{CTL}$ play an important role in immune-mediated destruction of autologous melanocytes. However, cellular cytotoxicity against melanocyte differentiation antigens may not be solely dependent on MHC class-I restricted $\mathrm{T}$ cells. Melan-A-specific $\mathrm{CD} 4^{+}-\mathrm{CTL}$ have been generated from patients with melanoma as well as from normal control donors (Rivoltini et al, 1998; Zarour et al, 2000). The in vivo activation of such $C D 4^{+}$ CTL may occur when professional APC, after endocytosis of dying melanocytes, migrate to skin-draining lymph nodes to present peptides derived from melanosomal antigens (Das et al, 2001). However, actual killing of melanocytes by MHC class-II restricted CTL also requires that target cells present endogenous melanosomal proteins in the context of MHC class-II molecules (Rivoltini et al, 1998). It is known that melanosomal glycoproteins are transported to the melanosomes by a dileucine-based sorting and retention motif, called the melanosomal transport signal (MTS) (Vijayasaradhi et al, 1995; Xu et al, 1998). Recently it was shown that this MTS motif can also target proteins to the endocytic pathway, leading to peptide presentation by MHC-class II molecules to 
helper T cells (Wang et al, 1999). This may provide an explanation for the observed in vitro recognition of endogenous melanocyte differentiation antigens by cytotoxic $\mathrm{CD}^{+} \mathrm{CTL}$. Moreover, because enhanced numbers of $\mathrm{MHC}$ class-II-expressing melanocytes were reported in perilesional skin (al Badri et al, 1993; Le Poole et al, 1996), quantitative changes in MTS trafficking may be an additional cause of CTLmediated melanocyte destruction in vitiligo.

A further role for $\mathrm{CD} 4^{+} \mathrm{T}$ cells in the autoimmune killing of melanocytes was indicated when melanocyte destruction in mice was evoked by active immunization against the TRP-2 melanocyte differentiation antigen. This response was, although mediated by $\mathrm{CD} 8^{+}$ $\mathrm{T}$ cells, also dependent on the presence of $\mathrm{CD} 4^{+} \mathrm{T}$ cells (Bowne et al, 1999). The importance of cellmediated responses was further emphasized by the predominant presence of type- $1 \mathrm{~T}$ cells at the perilesional site of active lesions. Type-1 T cells are involved in cell-mediated inflammatory reactions, whereas type-2 T cells are found in association with strong antibody responses. In a recent study, in vitro cytokine profiles of nonspecifically stimulated $T$ cell clones, derived from the border of the depigmented lesion, were compared with those of nonlesional skin. It was found that active vitiligo lesions are mainly infiltrated with type-1 T cells, whereas uninvolved skin contained type-2 and type- 0 subsets. Furthermore, some of these perilesional type-1-CD8 ${ }^{+} \mathrm{T}$ cells were able to kill autologous melanocytes in an HLA class-I restricted manner (Wankowicz-Kalinska et al, submitted for publication). Although these findings provide further evidence for the importance of autoreactive T cells in skin depigmentation (type-1 response in the border area), the observed type-2 response at the nonlesional site may play a role in restricting the exacerbation of disease (D'Ambrosio et al, 2000).

\section{Conclusion}

To date, three important hypotheses have been formulated to explain the etiology of vitiligo: the autoimmune, the self-destruction, and the neural theory. Although it cannot be excluded that the selfdestruction and neural hypotheses are applicable in subsets of vitiligo patients, recently obtained evidence strongly indicates that this pigmentary disorder is an autoimmune disease. This statement is further appreciated when regarding the current clinical practice of vitiligo management; all of the nonsurgical vitiligo treatments with proven efficacy (Njoo et al, 1998) are based on immunosuppression (Cato and Wade, 1996; Hill et al, 1999; Krutmann and Morita, 1999; Ozawa et al, 1999). Thus, future investigations in vitiligo etiology should focus on finding the exact conditions that trigger and sustain this melanocyte-specific autoimmune response. In relation to this, it is important to note that MHC class-I as well as MHC class-II restricted $T$ cells that recognize melanocyte differentiation antigens can be cultured from normal control donors (Ogg et al, 1998; Visseren et al, 1995; Zarour et al, 2000). Establishing the triggers that awaken this latent mechanism in vitiligo will not only benefit patients with this autoimmune disease, but may also be of considerable importance for melanoma therapy, where an effective immune response against melanocyte differentiation antigens is lacking.

\section{References}

Abdel-Naser MB, Kruger-Krasagakes S, Krasagakis K, Gollnick H, Abdel-Fattah A, and Orfanos CE (1994). Further evidence for involvement of both cell mediated and humoral immunity in generalized vitiligo. Pigment Cell Res 7:1-8.

al Badri AM, Foulis AK, Todd PM, Gariouch JJ, Gudgeon JE, Stewart DG, Gracie JA, and Goudie RB (1993). Abnormal expression of MHC class II and ICAM-1 by melanocytes in vitiligo. J Pathol 169:203-206.

Anichini A, Maccalli C, Mortarini R, Salvi S, Mazzocchi A, Squarcina P, Herlyn M, and Parmiani G (1993). Melanoma cells and normal melanocytes share antigens recognized by HLA-A2-restricted cytotoxic T cell clones from melanoma patients. J Exp Med 177:989-998.

Ardic FN, Aktan S, Kara CO, and Sanli B (1998). Highfrequency hearing and reflex latency in patients with pigment disorder. Am J Otolaryngol 19:365-369.

Badri AM, Todd PM, Garioch JJ, Gudgeon JE, Stewart DG, and Goudie RB (1993). An immunohistological study of cutaneous lymphocytes in vitiligo. J Pathol 170:149-155.

Becker JC, Guldberg P, Zeuthen J, Brecker EB, and Straten PT (1999). Accumulation of identical T cells in melanoma and vitiligo-like leukoderma. J Invest Dermatol 113:1033-1038.

Bowne WB, Srinivasan R, Wolchok JD, Hawkins WG, Blachere NE, Dyall R, Lewis JJ, and Houghton AN (1999). Coupling and uncoupling of tumor immunity and autoimmunity. J Exp Med 190:1717-1722.

Buc M, Busova B, Hegyi E, and Kolibasova K (1996). Vitiligo is associated with HLA-A2 and HLA-Dw7 in the Slovak populations. Folia Biol 42:23-25.

Buckley WR (1953). Vitiligo with raised inflammatory border. Arch Dermatol Syph 67:316-320.

Bustamante J, Bredeston L, Malanga G, and Mordoh J (1993). Role of melanin as a scavenger of active oxygen species. Pigment Cell Res 6:348-353.

Bystryn JC, Rigel D, Friedman RJ, and Kopf A (1987). Prognostic significance of hypopigmentation in malignant melanoma. Arch Dermatol 123:1053-1055.

Cato AC and Wade E (1996). Molecular mechanisms of anti-inflammatory action of glucocorticoids. Bioessays 18: 371-378.

Coulie PG, Brichard V, Van Pel A, Wolfel T, Schneider J, Traversari C, Mattei S, De Plaen E, Lurquin C, and Szikora JP (1994). A new gene coding for a differentiation antigen recognized by autologous cytolytic $T$ lymphocytes on HLA-A2 melanomas. J Exp Med 180:35-42.

D'Ambrosio D, lellem A, Colantonio L, Clissi B, Pardi R, and Sinigaglia $F$ (2000). Localization of Th-cell subsets in inflammation: Differential thresholds for extravasation of Th1 and Th2 cells. Immunol Today 21:183-186.

Danno K, Horio T, Takigawa M, and Imamura S (1984). Role of oxygen intermediates in UV-induced epidermal cell injury. J Invest Dermatol 83:166-168. 
Das SK, Majumder PP, Majumdar TK, and Haldar B (1985). Studies on vitiligo. II. Familial aggregation and genetics. Genet Epidemiol 2:255-262.

Das PK, van den Wijngaard RMJGJ, Wankowicz-Kalinska A, and Le Poole IC (2001). A symbiotic concept of autoimmunity and tumour immunity: Lessons from vitiligo. Trends Immunol 22:130-136.

Dunston GM and Halder RM (1990). Vitiligo is associated with HLA-DR4 in black patients: A preliminary report. Arch Dermatol 126:56-60.

Fishman P, Merimski O, Baharav E, and Shoenfeld Y (1997). Autoantibodies to tyrosinase: The bridge between melanoma and vitiligo. Cancer 79:1461-1464.

Foley LM, Lowe NJ, Misheloff E, and Tiwari JL (1983). Association of HLA-DR4 with vitiligo. J Am Acad Dermatol 8:39-40.

Garb J and Wise F (1948). Vitiligo with raised borders. Arch Dermatol Syph 58:149-153.

Gilhar A, Zelickson B, Ulman Y, and Etzioni A (1995). In vivo destruction of melanocytes by the lgG fraction of serum from patients with vitiligo. J Invest Dermatol 105:683-686.

Gould IM, Gray RS, Urbaniak SJ, Elton RA, and Duncan LJ (1985). Vitiligo in diabetes mellitus. Br J Dermatol 113:153155.

Gross A, Tapia FJ, Mosca W, Perez RM, Briceno L, Henriquez JJ, and Convit J (1987). Mononuclear cell subpopulations and infiltrating lymphocytes in erythema dyschromicum perstans and vitiligo. Histol Histopathol 2:277-283.

Hara I, Takechi Y, and Houghton AN (1995). Implicating a role for immune recognition of self in tumor rejection: Passive immunization against the brown locus protein. J Exp Med 182:1609-1614.

Harning R, Cui J, and Bystryn JC (1991). Relation between the incidence and level of pigment cell antibodies and disease activity in vitiligo. J Invest Dermatol 97:1078-1080.

Hearing VJ (1999). Biochemical control of melanogenesis and melanosomal organization. J Investig Dermatol Symp Proc 4:24-28.

Hegedus L, Heidenheim M, Gervil M, Hjalgrim H, and HoierMadsen M (1994). High frequency of thyroid dysfunction in patients with vitiligo. Acta Derm Venereol 74:120-123.

Hill LL, Shreedhar VK, Kripke ML, and Owen-Schaub LB (1999). A critical role for Fas ligand in the active suppression of systemic immune responses by ultraviolet radiation. J Exp Med 189:1285-1294.

Jager E, Maeurer M, Hohn H, Karbach J, Jager D, Zidianakis Z, Bakhshandeh-Bath A, Orth J, Neukirch C, Necker A, Reichert TE, and Knuth A (2000). Clonal expansion of Melan A-specific cytotoxic $T$ lymphocytes in a melanoma patient responding to continued immunization with melanomaassociated peptides. Int J Cancer 86:538-547.

Jimbow K, Quevedo WC, Fitzpatrick TB, and Szabo G (1993). Biology of melanocytes. In: Fitzpatrick TB, editor. Dermatology in general medicine, 4th ed. New York: McGraw-Hill, 261-289.

Kemp EH, Ajjan RA, Husebye ES, Peterson P, Uibo R, Imrie H, Pearce SH, Watson PF, and Weetman AP (1998a). A cytotoxic $T$ lymphocyte antigen-4 (CTLA-4) gene polymorphism is associated with autoimmune Addison's disease in English patients. Clin Endocrinol (Oxf) 49:609-613.
Kemp EH, Ajjan RA, Waterman EA, Gawkrodger DJ, Cork MJ, Watson PF, and Weetman AP (1999). Analysis of a microsatellite polymorphism of the cytotoxic T-lymphocyte antigen-4 gene in patients with vitiligo. Br J Dermatol 140:73-78.

Kemp EH, Gawkrodger DJ, MacNeil S, Watson PF, and Weetman AP (1997). Detection of tyrosinase autoantibodies in patients with vitiligo using 35S-labeled recombinant human tyrosinase in a radioimmunoassay. $J$ Invest Dermatol 109:69-73.

Kemp EH, Gawkrodger DJ, Watson PF, and Weetman AP (1998b). Autoantibodies to human melanocyte-specific protein pmel17 in the sera of vitiligo patients: A sensitive and quantitative radioimmunoassay (RIA). Clin Exp Immunol 114: 333-338.

Kemp EH, Waterman EA, Gawkrodger DJ, Watson PF, and Weetman AP (1998c). Autoantibodies to tyrosinase-related protein-1 detected in the sera of vitiligo patients using a quantitative radiobinding assay. Br J Dermatol 139:798-805.

Kobayashi N, Nakagawa A, Muramatsu T, Yamashina Y, Shirai T, Hashimoto MW, Ishigaki Y, Ohnishi T, and Mori T (1998). Supranuclear melanin caps reduce ultraviolet induced DNA photoproducts in human epidermis. J Invest Dermatol 110:806-810.

Kotsa K, Watson PF, and Weetman AP (1997). A CTLA-4 gene polymorphism is associated with both Graves disease and autoimmune hypothyroidism. Clin Endocrinol (Oxf) 46: 551-554.

Kovacs SO (1998). Vitiligo. J Am Acad Dermatol 38:647-666.

Krutmann $\mathrm{J}$ and Morita A (1999). Mechanisms of ultraviolet (UV) B and UVA phototherapy. J Investig Dermatol Symp Proc 4:70-72.

Kunisada T, Yoshida H, Yamazaki H, Miyamoto A, Hemmi H, Nishimura E, Shultz LD, Nishikawa S, and Hayashi S (1998). Transgene expression of steel factor in the basal layer of epidermis promotes survival, proliferation, differentiation, and migration of melanocyte precursors. Development 125: 2915-2923.

Le Poole IC and Boyce ST (1999). Keratinocytes suppress transforming growth factor-beta1 expression by fibroblasts in cultured skin substitutes. Br J Dermatol 140:409-416.

Le Poole IC, Mutis T, van den Wijngaard RM, Westerhof W, Ottenhoff T, de Vries RR, and Das PK (1993a). A novel, antigen-presenting function of melanocytes and its possible relationship to hypopigmentary disorders. J Immunol 151: 7284-7292.

Le Poole IC, van den Wijngaard RM, Westerhof W, and Das PK (1996). Presence of T cells and macrophages in inflammatory vitiligo skin parallels melanocyte disappearance. Am J Pathol 148:1219-1228.

Le Poole IC, van den Wijngaard RM, Westerhof W, Dutrieux RP, and Das PK (1993b). Presence or absence of melanocytes in vitiligo lesions: An immunohistochemical investigation. J Invest Dermatol 100:816-822.

Le Poole IC, van den Wijngaard RM, Westerhof W, Verkruisen RP, Dutrieux RP, Dingemans KP, and Das PK (1993c). Phagocytosis by normal human melanocytes in vitro. Exp Cell Res 205:388-395.

Lerner AB (1959). Vitiligo. J Invest Dermatol 32:285-310.

Lim HW and Cooper K (1999). The health impact of solar radiation and prevention strategies: Report of the Environ- 
ment Council, American Academy of Dermatology. J Am Acad Dermatol 41:81-99.

Majumder PP, Nordlund JJ, and Nath SK (1993). Pattern of familial aggregation of vitiligo. Arch Dermatol 129:994-998.

McCoy KD and Le Gros G (1999). The role of CTLA-4 in the regulation of $\mathrm{T}$ cell immune responses. Immunol Cell Biol 77:1-10.

McGregor WG (1999). DNA repair, DNA replication, and UV mutagenesis. J Invest Dermatol Symp Proc 4:1-5.

Metzker A, Zamir R, Gazit E, David M, and Feuerman EJ (1980). Vitiligo and the HLA system. Dermatologica 160:100105.

Michaelsson G (1968). Vitiligo with raised borders. Acta Derm Venereol 48:158-161.

Mosher DB, Fitzpatrick TB, Hori Y, and Ortonne JP (1993). Disorders of melanocytes. In: Fitzpatrick TB, editor. Dermatology in general medicine, 4th ed. New York: McGraw-Hill, 903-995.

Naftzger C, Takechi Y, Kohda H, Hara I, Vijayasaradhi S, and Houghton A (1996). Immune response to a differentiation antigen induced by altered antigen: A study of tumor rejection and autoimmunity. Proc Natl Acad Sci USA 93:1480914814.

Naughton GK, Eisinger M, and Bystryn JC (1983a). Antibodies to normal human melanocytes in vitiligo. J Exp Med 158:246-251.

Naughton GK, Eisinger M, and Bystryn JC (1983b). Detection of antibodies to melanocytes in vitiligo by specific immunoprecipitation. J Invest Dermatol 81:540-542.

Nishimura EK, Yoshida H, Kunisada T, and Nishikawa SI (1999). Regulation of E- and P-cadherin expression correlated with melanocyte migration and diversification. Dev Biol 215:155-166.

Njoo MD, Spuls PI, Bos JD, Westerhof W, and Bossuyt PM (1998). Nonsurgical repigmentation therapies in vitiligo: Meta-analysis of the literature. Arch Dermatol 134:15321540.

Nordlund JJ, Kirkwood JM, Forget BM, Milton G, Albert DM, and Lerner $A B$ (1983). Vitiligo in patients with metastatic melanoma: A good prognostic sign. J Am Acad Dermatol 9:689-696.

Norris DA, Kissinger RM, Naughton GM, and Bystryn JC (1988). Evidence for immunologic mechanisms in human vitiligo: Patients' sera induce damage to human melanocytes in vitro by complement-mediated damage and antibodydependent cellular cytotoxicity. J Invest Dermatol 90:783789 .

Ogg GS, Rod Dunbar P, Romero P, Chen JL, and Cerundolo $V$ (1998). High frequency of skin-homing melanocyte-specific cytotoxic T lymphocytes in autoimmune vitiligo. J Exp Med 188:1203-1208.

Overwijk WW, Lee DS, Surman DR, Irvine KR, Touloukian CE, Chan CC, Carroll MW, Moss B, Rosenberg SA, and Restifo NP (1999). Vaccination with a recombinant vaccinia virus encoding a "self" antigen induces autoimmune vitiligo and tumor cell destruction in mice: Requirement for CD4(+) T lymphocytes. Proc Natl Acad Sci USA 96:2982-2987.

Ozawa M, Ferenczi K, Kikuchi T, Cardinale I, Austin LM, Coven TR, Burack LH, and Krueger JG (1999). 312nanometer ultraviolet $B$ light (narrow-band UVB) induces apoptosis of $\mathrm{T}$ cells within psoriatic lesions. J Exp Med 189:711-718.

Park S, Albert DM, and Bolognia JL (1992). Ocular manifestations of pigmentary disorders. Dermatol Clin 10:609-622.

Picker LJ, Michie SA, Rott LS, and Butcher EC (1990). A unique phenotype of skin-associated lymphocytes in humans: Preferential expression of the HECA-452 epitope by benign and malignant T cells at cutaneous sites. Am J Pathol 136:1053-1068.

Pittet MJ, Valmori D, Dunbar PR, Speiser DE, Lienard D, Lejeune F, Fleischhauer K, Cerundolo V, Cerottini JC, and Romero P (1999). High frequencies of naive Melan-A/MART1-specific $\mathrm{CD} 8(+) \mathrm{T}$ cells in a large proportion of human histocompatibility leukocyte antigen (HLA)-A2 individuals. J Exp Med 190:705-715.

Porter J, Beuf AH, Nordlund JJ, and Lerner AB (1979). Psychological reaction to chronic skin disorders: A study of patients with vitiligo. Gen Hosp Psychiatry 1:73-77.

Riley PA (1994). Free radicals in biology: Oxidative stress and the effects of ionizing radiation. Int $\mathrm{J}$ Radiat Biol 65:27-33.

Rivoltini L, Radrizzani M, Accornero P, Squarcina P, Chiodoni C, Mazzocchi A, Castelli C, Tarsini P, Viggiano V, Belli F, Colombo MP, and Parmiani G (1998). Human melanomareactive $\mathrm{CD} 4+$ and $\mathrm{CD} 8+\mathrm{CTL}$ clones resist Fas ligandinduced apoptosis and use Fas/Fas ligand-independent mechanisms for tumor killing. J Immunol 161:1220-1230.

Rosenberg SA (1997). Cancer vaccines based on the identification of genes encoding cancer regression antigens. Immunol Today 18:175-182.

Sanchez-Ferrer A, Rodriguez-Lopez JN, Garcia-Canovas F, and Garcia-Carmona F (1995). Tyrosinase: A comprehensive review of its mechanism. Biochim Biophys Acta 1247:1-11.

Smit N, Le Poole I, van den Wijngaard R, Tigges A, Westerhof W, and Das P (1993). Expression of different immunological markers by cultured human melanocytes. Arch Dermatol Res 285:356-365.

Song $\mathrm{YH}$, Connor $\mathrm{E}, \mathrm{Li} \mathrm{Y}$, Zorovich $\mathrm{B}$, Balducci $\mathrm{P}$, and Maclaren $N$ (1994). The role of tyrosinase in autoimmune vitiligo. Lancet 344:1049-1052.

Takechi Y, Hara I, Naftzger C, Xu Y, and Houghton AN (1996). A melanosomal membrane protein is a cell surface target for melanoma therapy. Clin Cancer Res 2:1837-1842.

Uda H, Takei M, and Mishima Y (1984). Immunopathology of vitiligo vulgaris, Sutton's leukoderma and melanomaassociated vitiligo in relation to steroid effects. II. The IgG and C3 deposits in the skin. J Cutan Pathol 11:114-124.

van den Wijngaard R, Wankowicz-Kalinska A, Le Poole C, Tigges B, Westerhof W, and Das P (2000). Local immune response in skin of generalized vitiligo patients: Destruction of melanocytes is associated with the prominent presence of CLA+T cells at the perilesional site. Lab Invest 80:12991309.

Venneker GT, de Waal LP, Westerhof W, D'Amaro J, Schreuder GM, and Asghar SS (1993). HLA associations in vitiligo patients in the Dutch population. Dis Markers 11:187-190.

Vijayasaradhi S, Xu Y, Bouchard B, and Houghton AN (1995). Intracellular sorting and targeting of melanosomal membrane proteins: Identification of signals for sorting of the human brown locus protein, gp75. J Cell Biol 130:807-820. 
Visseren MJ, van Elsas A, van der Voort El, Ressing ME, Kast WM, Schrier PI, and Melief CJ (1995). CTL specific for the tyrosinase autoantigen can be induced from healthy donor blood to lyse melanoma cells. J Immunol 154:3991-3998.

Wang S, Bartido S, Yang G, Qin J, Moroi Y, Panageas KS, Lewis JJ, and Houghton AN (1999). A role for a melanosome transport signal in accessing the MHC class II presentation pathway and in eliciting CD4+ T cell responses. J Immunol 163:5820-5826.

Weber LW, Bowne WB, Wolchok JD, Srinivasan R, Qin J, Moroi Y, Clynes R, Song P, Lewis JJ, and Houghton AN (1998). Tumor immunity and autoimmunity induced by immunization with homologous DNA. J Clin Invest 102:1258-1264.

Wehrle-Haller B and Weston JA (1995). Soluble and cellbound forms of steel factor activity play distinct roles in melanocyte precursor dispersal and survival on the lateral neural crest migration pathway. Development 121:731-742.

Xu Y, Vijayasaradhi S, and Houghton AN (1998). The cytoplasmic tail of the mouse brown locus product determines intracellular stability and export from the endoplasmic reticulum. J Invest Dermatol 110:324-331.

Yagi H, Tokura Y, Furukawa F, and Takigawa M (1997). Vitiligo with raised inflammatory borders: Involvement of $T$ cell immunity and keratinocytes expressing MHC class II and ICAM-1 molecules. Eur J Dermatol 7:19-22.

Yamamoto O and Bhawan J (1994). Three modes of melanosome transfers in Caucasian facial skin: Hypothesis based on an ultrastructural study. Pigment Cell Res 7:158-169.
Yee C, Thompson JA, Roche P, Byrd DR, Lee PP, Piepkorn M, Kenyon K, Davis MM, Riddell SR, and Greenberg PD (2000). Melanocyte destruction after antigen-specific immunotherapy of melanoma: Direct evidence of T cell-mediated vitiligo. J Exp Med (192): 1637-1644.

Yu HS, Kao CH, and Yu CL (1993). Coexistence and relationship of antikeratinocyte and antimelanocyte antibodies in patients with non-segmental-type vitiligo. J Invest Dermatol 100:823-828.

Zachariae CO, Thestrup-Pedersen $\mathrm{K}$, and Matsushima $\mathrm{K}$ (1991). Expression and secretion of leukocyte chemotactic cytokines by normal human melanocytes and melanoma cells. J Invest Dermatol 97:593-599.

Zarour HM, Kirkwood JM, Kierstead LS, Herr W, Brusic V, Slingluff CL, Jr, Sidney J, Sette A, and Storkus WJ (2000). Melan-A/MART-1(51-73) represents an immunogenic HLADR4-restricted epitope recognized by melanoma-reactive CD4(+) T cells. Proc Natl Acad Sci USA 97:400-405.

Zauli D, Tosti A, Biasco G, Miserocchi F, Patrizi A, Azzaroni D, Andriani G, Di Febo G, and Callegari C (1986). Prevalence of autoimmune atrophic gastritis in vitiligo. Digestion 34:169172 . 